\title{
Pengaruh Penggunaan Ampas Kecap Terhadap Kecernaan Protein, Kalsium dan Energi Metabolis Itik Mojosari Petelur
}

\section{Effect of Dietary Supplementation of Soy Sauce Waste on Protein, Calcium and Metabolic Energy Digestibility of Mojosari Laying Ducks}

\author{
R. E. Purwandani*, L. D. Mahfudz dan U. Atmomarsono \\ Fakultas Peternakan dan Pertanian, Universitas Diponegoro, Semarang, 50275 \\ *E-mail: rimaekap@gmail.com
}

(Diterima: 27 Juli 2017; Disetujui: 20 September 2017)

\begin{abstract}
ABSTRAK
Penelitian ini bertujuan untuk mengetahui pengaruh penggunaan ampas kecap terhadap kecernaan protein, kalsium dan energi metabolis itik mojosari petelur. Materi yang digunakan adalah Itik Mojosari Petelur umur 20 minggu dengan BB rata - rata 1.385,0 $\pm 130,85$ gram (CV=9,44\%) sebanyak 240 ekor. Rancangan percobaan yang digunakan adalah Rancangan Acak Lengkap dengan 4 perlakuan dan 6 kali ulangan dan setiap ulangan terdiri dari 10 ekor itik. Perlakuan yang digunakan adalah dengan penggunaan ampas kecap dalam ransum dengan level $0,00 \%, 5,00 \%, 7,50 \%$ dan 10,00\%. Parameter yang diamati adalah kecernaan protein, kecernaan kalsium dan kecernaan energi metabolis. Data yang diperoleh dianalisis ragam dengan uji $\mathrm{F}$, apabila ada pengaruh perlakuan yang nyata dilanjutkan dengan uji wilayah ganda Ducan. Hasil menunjukan bahwa penggunaan ampas kecap dalam ransum tidak berpengaruh nyata $(\mathrm{P}>0,05)$ terhadap kecernaan protein, kalsium dan energi metabolis itik Mojosari petelur. Kesimpulan dari penelitian ini adalah ampas kecap dapat digunakan dalam ransum Itik Mojosari Petelur, sampai level 10\%.
\end{abstract}

Kata kunci: Itik Mojosari petelur, ampas kecap, kecernaan protein, kalsium, energi metabolis

\section{ABSTRACT}

This research ware aimed to study the effect utilization of soy sauce waste on protein, calcium and metabolic energy digestibility. The materials used were 240 Mojosari laying ducks at 20 weeks old with averages weight $1385.00 \pm 130.85$ gram $(C V=9.44 \%)$. The experimental design was a completely randomized design with 4 treatments and 6 replications, and each treatment consisted 10 Mojosari laying ducks. The treatments used ware soy sauce waste on the diet at levels 0.00; 5.00; 7.50 and 10.00\%. The variables observed were protein, calcium, and metabolic energy digestibility. The data were analyzed using analysis of variance if there is signification effect continued by Duncan' multiple range test. The result showed that no significant $(P>0.05)$ effect on protein, calcium, and metabolic energy digestibility. In conclusion, the soy sauce waste can be used as feedstuff on the diet Mojosari laying ducks.

Keywords: Mojosari laying ducks, soy sauce waste, digestibility protein, calcium and metabolic energy

\section{PENDAHULUAN}

Itik Mojosari petelur merupakan salah satu ternak unggas yang produksi telurnya termasuk tinggi. Produksi telur itik Mojosari yang tinggi tersebut diharapkan dapat memenuhi kebutuhan produk pangan protein hewani khususnya dari telur. Telur merupakan salah satu sumber protein hewani yang harga jualnya relatif lebih murah jika dibandingkan sumber protein hewani lainnya seperti daging. Peningkatan permintaan telur itik tersebut umumnya peternak masih belum mengetahui manajemen pemberian pakan yang baik, sehingga pakan yang diberikan belum mencukupi kecukupan nutrisi ternak dan mengakibatkan tingkat kecernaan pada ternak menjadi rendah. Tingkat kecernaan yang rendah pada ternak dapat menggangu produktivitas ternak, karena nutrisi pada 
pakan yang diberikan tidak terserap dengan baik.

Ampas kecap mengadung sekitar $60 \%$ protein kedelai yang tertinggal setelah proses fermentasi. Ampas kecap masih mengandung protein yang tinggi sekitar 24,90 $\%$ (Widyawati dan Widalestari, 1996). Ampas kecap mengandung zat aktif berupa senyawa isoflavon. Senyawa isoflavon terdapat dalam bentuk aglikon yang mudah diserap oleh usus. Senyawa isoflavon dalam ampas kecap dapat mempercepat penyerapan nutrisi dengan cara mengoptimalkan metabolis bakteri yang terdapat dalam saluran pencernaan. Senyawa isoflavon juga berfungsi sebagai antioksidan, dengan adanya antioksidan maka ternak dapat meningkatkan sistem immun yang berfungsi untuk menangkal radikal bebas yang ada di dalam tubuh. Radikal bebas yang terhambat membuat ternak dalam kodisi sehat, yang berakibat proses kecernaan ternak dapat berlangsung optimal. Ampas kecap selain memiliki kelebihan juga memiliki kelemahan karenamemilikikandungan garam $(\mathrm{NaCl})$ yang cukup tinggi. Kadar garam yang terkandung di dalam ampas kecap perlu diturunkan dengan perendaman mengunakan asam asetat (5\%) selama 24 jam dan kemudian dicuci dengan air mengalir, sehingga $\mathrm{pH}$ menjadi normal, dilakukan penirisan, penjemuran dan penggilingan sebelum diberikan untuk unggas (Sukarini et al., 2004).

Penelitian ini bertujuan untuk mengkaji pengaruh beberapa level pemberian $(0 \%$; $5 \% ; 7,5 \%$ dan $10 \%$ ) ampas kecap pada pakan terhadap kecernaan protein, kalsium dan energi metabolis itik Mojosari petelur. Manfaat dari penelitian ini adalah untuk mendapat informasi pemanfaatan limbah ampas kecap dalam pakan terhadap nilai kecernaan protein, kalsium dan energi metabolis Itik Mojosari petelur.

\section{METODE}

Penelitian dengan Judul "Penggunaan ampas kecap dalam ransum terhadap kecernaan protein, kalsium dan energi metabolis Itik Mojosari Petelur" dilaksanakan pada bulan Desember 2016 - Januari 2017 di Universitas Darul Ulum Islamic Center Sudirman (UNDARIS), Ungaran, Jawa Tengah.

Materi yang digunakan dalam penelitian yaitu Itik Mojosari Petelur Umur 20 minggu sebanyak 240 ekor dengan bobot badan rata - rata $1.385,0 \pm 130,85$ gram $(\mathrm{CV}=9,44 \%)$. Ampas kecap yang digunakan diperoleh dari perusahaan kecap merk "Lele" dan bahan ransum (bekatul, bungkil kedelai, jagung kuning, tepung ikan, pollard dan premix). Peralatan yang digunakan terdiri kandang battery, serta peralatan kandang yang terdiri dari timbangan gantung kapasitas $50 \mathrm{~kg}$ dan timbangan digital $10 \mathrm{~kg}$ tempat minum, tempat pakan, Semprotan, thermohygrometer. Bahan lain adalah HCL 0,1 N untuk mengikat nitrogen dalam ekskreta dan vitamin egg suplemen untuk meningkatkan produktivitas telur.

Metode yang dilakukan dengan mengunakan metode rancangan acak lengkap (RAL) dengan 4 perlakuan 6 ulangan, sehingga ada 24 unit percobaan dimana setiap unit terdapat 10 ekor Itik Mojosari Petelur. Perlakuan T0: Ransum tanpa Ampas Kecap, T1: Ransum mengandung Ampas Kecap 5\%, T2: Ransum mengandung Ampas kecap 7,5\%, T3: Ransum mengandung Ampas Kecap 10\% (Tabel 1). Pembuatan pakan ampas kecap dari limbah penggolahan kecap merk "Lele", dengan melakukan perendaman dengan menggunakan asam asetat 5\% selama 24 jam, kemudian di cuci dengan air mengalir, dan dilakukan penjemuran dibawah sinar matahari selama 1 - 2 hari hingga kering. Pelaksaan penelitian dengan cara melakukan pengacakan itik saat duck in. pemberian pakan dilakukan 2 kali pagi dan sore hari. Kandang battery digunakan untuk pengambilan data pada total koleksi, jumlah kandang battery yang digunakan sebanyak 24 unit setiap unit kandang battery ditempati satu ekor itik. Penampungan ekskreta dalam total koleksi dilakukan selama 3 hari. Tahap pengumpulan 
Tabel 1. Hasil analisis kandungan nutrisi ransum berdasarkan kering udara.

\begin{tabular}{llcccccc}
\hline \multirow{2}{*}{ No } & \multirow{2}{*}{ Bahan Pakan } & \multicolumn{7}{c}{ Kandungan nutrisi } \\
\cline { 2 - 7 } & & $\mathrm{EM}^{*}(\mathrm{kkal} / \mathrm{kg})$ & $\mathrm{PK}^{*}(\%)$ & $\mathrm{LK}^{*}(\%)$ & $\mathrm{SK}^{*}(\%)$ & $\mathrm{Ca}^{* *}(\%)$ & $\mathrm{P}^{* *}(\%)$ \\
\hline 1 & Ampas Kecap & 3924,14 & 28,78 & 1,84 & 46,17 & $1,70^{*}$ & $0,70^{*}$ \\
2 & Jagug Kuning & 2785,32 & 9,40 & 4,22 & 2,44 & 0,03 & 0,23 \\
3 & Tepung Ikan & 2091,40 & 37,33 & 5,18 & 2,31 & 12,08 & 3,05 \\
4 & Bekatul & 3395,00 & 12,06 & 13,58 & 8,39 & 0,32 & 1,70 \\
5 & Pollard & 2587,10 & 13,46 & 0,70 & 4,48 & 0,09 & 0,78 \\
6 & Bungkil kedelai & 2985,05 & 42,84 & 3,00 & 1,90 & 0,24 & 0,57 \\
7 & Premix & 959,430 & 5,26 & 4,23 & 3,35 & $3,30^{*}$ & $3,50^{*}$ \\
\hline
\end{tabular}

* Hasil Analisis Proksimat Laboratorium Ilmu Nutrisi dan Pakan, Fakultas Peternakan dan Pertanian, Universitas Diponegoro, 2016.

** Hartadi, 1997

Tabel 2. Komposisi dan Kandungan Nutrisi Ransum Perlakuan

\begin{tabular}{lrrrr}
\hline Bahan Pakan : & $\mathrm{T} 0$ & $\mathrm{~T} 1$ & $\mathrm{~T} 2$ & $\mathrm{~T} 3$ \\
\hline Ampas Kecap (\%) & 0,00 & 5,00 & 7,50 & 10,00 \\
Bekatul (\%) & 26,20 & 20,00 & 16,50 & 13,70 \\
Bungkil Kedelai (\%) & 17,60 & 14,70 & 13,50 & 12,00 \\
Tepung Ikan (\%) & 7,00 & 7,20 & 7,00 & 7,10 \\
Pollard (\%) & 6,50 & 11,50 & 13,50 & 16,50 \\
Premix (\%) & 1,00 & 1,00 & 1,00 & 1,00 \\
Jagung Kuning (\%) & 41,70 & 40,60 & 41,00 & 39,70 \\
Total & 100,00 & 100,00 & 100,00 & 100,00 \\
Kandungan Nutrisi : & & & & \\
Protein Kasar (\%) & 18,07 & 18,09 & 18,08 & 18,10 \\
Lemak Kasar (\%) & 6,30 & 5,46 & 5,01 & 4,61 \\
Serat Kasar (\%) & 4,04 & 5,97 & 6,91 & 7,90 \\
Kalsium (\%) & 1,02 & 1,11 & 1,12 & 1,16 \\
Posfor (\%) & 0,94 & 0,90 & 0,86 & 0,84 \\
EM (kkal/kg) & $2.900,00$ & $2.903,00$ & $2.905,00$ & $2.906,00$ \\
\hline
\end{tabular}

* Hasil Analisis Proksimat Laboratorium Ilmu Nutrisi dan Pakan, Fakultas Peternakan dan Pertanian, Universitas Diponegoro, 2016.

data dengan parameter kecernaan protein menggunakan rumus Mc Donald et al. (1977):

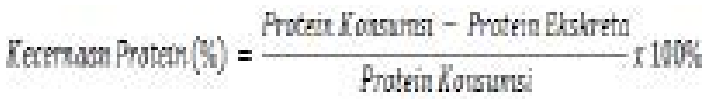

Keterangan:

Protein konsumsi $=$ Jumlah konsumsi $\mathrm{x}$ Protein pakan

Protein ekskreta $=$ Jumlah ekskreta $\mathrm{x}$ Protein ekskreta

Kecernaan Kalsium dihitung dengan menggunakan rumus Tavernari dkk. (2008) dikutip oleh Leke et al. (2012) sebagai berikut:

$$
A M C(\%)=\frac{M t i-M t e}{M t i} \times 100 \%
$$

Keterangan:

$$
\begin{array}{ll}
\text { AMC } & =\text { Kecernaan Kalsium } \\
\text { Mti } & =\text { Total mineral pakan } \\
\text { Mte } & =\text { Total mineral eksreta }
\end{array}
$$

Kecernaan Energi Metabolis diukur dengan rumus Min et al. (2009): 


$$
\text { Kecernaan Energl }(\%)=\frac{A M E}{G E \text { Pakan }}
$$

Keterangan:

$\mathrm{AME}=$ Apparent Metabolizable energy

GE Pakan = Gross Energy pakan

Data dianalisis ragam atau analyze of variance dengan uji $\mathrm{F}$ pada taraf $5 \%$ dan 1 $\%$ untuk mengetahui pengaruh perlakuan. Apabila ada pengaruh perlakuan dilanjutkan uji Duncan.

\section{HASIL DAN PEMBAHASAN}

Berdasarkan hasil penelitian diketahui hasil rataan Kecernaan Protein, Kalsium dan Energi Metabolis Itik Mojosari Petelur dengan penggunaan ampas kecap dalam pakan disajikan dalam Tabel 3.

\section{Pengaruh Penggunaan Ampas Kecap Terhadap Kecernaan Protein Itik Mojosari Petelur}

Hasil rataan kecernaan protein ampas kecap Itik Mojosari Petelur pada penelitian berkisar 80,88-86,72\% dan hasil ini tergolong tinggi. Menurut Maghfiroh et al. (2012) bahwa tingkat kecernaan protein dikatakan tinggi apabila $>70 \%$, sedang $50-70 \%$ dan rendah apabila $50-60 \%$. Hal ini didukung pendapat Leke et al. (2012) kecernan protein pada itik berkisar $75-90 \%$. Analisis ragam penggunaan ampas kecap dalam pakan tidak berpengaruh nyata $(\mathrm{P}>0,05)$ terhadap kecernaan protein Itik Mojosari Petelur. Tingkat konsusmsi pakan juga menentukan tingkat konsumsi protein yang dikonsumsi itik, semakin banyak pakan yang dikonsumsi itik pakan protein yang dikonsumsi semakin tinggi juga. Menurut Winedar et al. (2006) bahwa besarnya nilai kecernaan protein pakan tergantung oleh jumlah protein yang dikonsumsi. Penggunaan ampas kecap memberikan pengaruh yang tidak berbeda nyata, hal ini dapat disebabkan oleh konsumsi pakan yang juga tidak berbeda nyata $(\mathrm{P}>0,05)$, selain itu tingkat konsumsi protein dan isoflavon masih dalam taraf yang sama. Menurut Herdiana et al. (2014) bahwa tingkat konsumsi pakan akan mempengaruhi tingkat protein yang tercerna.

Ampas kecap mengandung senyawa isolavon yang merupakan senyawa aktif yang dapat ditemui dalam bentuk aglikon isoflavon mudah dicerna dalam usus halus. Selain itu isoflavon juga dapat meningkatkan metabolis bakteri dalam saluran pencernaan. Peningkatan aktivitas metabolis bakteri tersebut dapat berakibat meningkatnya nutrient yang dapat diserap oleh saluran pencernaan itik menjadi lebih tinggi. Isoflavon juga berfungsi sebagai antioksidan dan sistem kekebalan tubuh. Menurut Payne et al. (2001) bahwa isoflavon memiliki sifat biologis bagi tubuh diantaranya meningkatkan sistem kekebalan tubuh.

Taraf penggunaan ampas kecap dalam pakan juga mempengaruhi tingkat konsumsi isoflavon dalam pakan. Tingkat isoflavon yang dikonsumsi oleh itik sekitar $0-0,2005$ gram, tingkat konsumsi tersebut belum mempengaruhi kadar isoflavon yang ada, sehingga konsumsi isoflavon pada perlakuan T0, T1, T2 dan T3 dalam jumlah yang sama, memberikan efek yang sama juga pada itik. Menurut Malik et al. (2015) bahwa ampas kecap mengandung isoflavon 13,68 mg/g.

\section{Pengaruh Penggunaan Ampas Kecap Terhadap Kecernaan Kalsium Itik Mojosari Petelur}

Hasil rataan kecernaan kalsium ampas kecap Itik Mojosari Petelur pada penelitian ini berkisar $71,12-82,48 \%$ tingkat kecernaan kalsium tersebut tergolong tinggi. Berdasarkan analisis ragam penggunaan ampas kecap dalam pakan tidak berpengaruh nyata $(\mathrm{P}>0,05)$ terhadap kalsium itik Mojosari petelur. Hal ini dipengaruhi oleh tingkat konsumsi kalsium dan isoflavon dalam taraf yang sama sehingga efek yang terjadi pada ternak juga sama.

Kecernaan kalsium yang tinggi mengkibatkan proses pembentukan telur terjadi sempurna, selain itu kalsium juga berfungsi untuk menjaga kesehatan tulang. Ampas kecap terdapat dalam bentuk isoflavon yang berfungsi untuk menjaga pengeroposan tulang. Hal ini Menurut Atun (2009) bahwa 
Tabel 3. Hasil Rataan Kecernaan Protein, Kalsium dan Energi Metabolis Itik Mojosari Petelur.

\begin{tabular}{lcccc}
\hline \multirow{2}{*}{ Parameter } & \multicolumn{4}{c}{ Perlakuan } \\
\cline { 2 - 5 } & T0 & T1 & T2 & T3 \\
\hline Kecernaan Protein (\%) & 81,06 & 80,88 & 86,72 & 83,61 \\
Kecernaan Kalsium (\%) & 74,10 & 71,12 & 79,04 & 82,48 \\
Kecernaan Energi Metabolis (\%) & 83,37 & 84,96 & 87,86 & 85,89 \\
\hline
\end{tabular}

Keterangan: Analisis ragam menujukan tidak berbeda nyata $(\mathrm{P}>0,05)$.

ampas kecap mengandung senyawa isoflavon yang dapat melindungi ternak dari kerusakan tulang/ osteopotosis sehingga kepadatan tulang tetap terjaga.

Kecernaan kalsium pada itik juga dipengaruhi oleh ada tidaknya zat anti nutrisi yang terdapat dalam pakan. Zat anti nutrisi dalam pakan dapat memberikan dampak negatif bila dikonsumsi oleh itik, sehingga dapat menganggu produktivitas, pertumbuhan serta menurunkan nilai kecernaan itik. Ampas kecep telah menggalami proses pemanasan dan fermentasi yang dapat menghilangkan zat anti nutrisi yang ada. Menurut Maghfiroh et al. (2014) bahwa ada tidaknya zat anti nutrisi dalam pakan dapat mempengaruhi tingkat kecernaan kalsium dan absorsi nutrient lain menjadi rendah.

\section{Pengaruh Penggunaan Ampas Kecap Terhadap Kecernaan Energi Metabolis Itik Mojosari Petelur}

Hasil rataan kecernaan energi metabolis ampas kecap Itik Mojosari Petelur pada penelitian ini berkisar $83,37-87,86 \%$. Nilai kecernaan energi metabolis tersebut termasuk tinggi. Menurut Rambet et al. (2016) bahwa nilai kecernaan energi unggas untuk daerah tropis berkisar $60-85 \%$. Berdasarkan analisis ragam penggunaan ampas kecap dalam pakan tidak berpengaruh nyata $(\mathrm{P}>0,05)$ terhadap Energi Metabolis Itik Mojosari Petelur. Hal ini dipengaruhi oleh konsumsi isoflavon dalam taraf yang sama, selain itu itik berada pada fase dan umur yang sama, dimana energi dalam pakan digunakan itik untuk pemeliharaan fungsi tubuh, pembentukan telur dan mengatur reaksi sintesis dalam tubuh.

Konsumsi isoflavon dalam jumlah taraf
$0-0,2005$ gram sudah membuat kecernaan energi metabolis itik tidak terganggu, hal ini karena senyawa isoflavon yang dikonsumsi juga berfungsi sebagai antioksidan. Antioksidan berfungsi untuk menangkal radikal bebas, yang dapat meningkatkan sistem immun dalam tubuh sehingga ternak menjadi sehat dan kecernaan energi metabolis meningkat. Menurut Malik et al. (2015) bahwa ampas kecap mengandung senyawa isoflavon yang berfungsi sebagai antioksidan. Hal ini diduga karena semakin banyak ampas kecap yang dikonsumsi, maka senyawa isoflavon juga semakin meningkat, dan senyawa aglikon yang terbentuk semakin banyak. Sehingga, dapat meningkatkan nilai kecernaan energi metabolis.

Senyawa isoflavon sendiri dipengaruhi oleh proses pemanasan dan fermentasi. Menurut Atun (2009) bahwa proses fermentasi dapat meningkatkan senyawa isoflavon.

\section{KESIMPULAN}

Ampas kecap dapat digunakan dalam ransum Itik Mojosari Petelur, sampai level $10 \%$.

\section{DAFTAR PUSTAKA}

Atun, S. 2009. Potensi senyawa isoflavon dan derivatnya dari kedelai (Glycine max. L) serta manfaatnya untuk kesehatan. Prosiding Semiar Nasional pendidikan dan penerapan MIPAUniversitas Negeri Yogyakarta. 16 Mei 2009. Universitas Negeri Yogyakarta. Yogyakarta. Hal : $33-41$. 
Hartadi, H., S. Reksohadiprojo dan A. D. Tilman. 1997. Tabel Komposisi Pakan Untuk Indonesia. Cetakan Keempat, Gadjah Mada University Press, Yogyakarta.

Herdiana, R. M., Y. Marshal, D. Ratih dan Sudiyono. 2014. Pengaruh penggunaan ampas kecap dalam pakan terhadap pertambahan bobot badan harian, konversi pakan, rasio efisiensi protein, dan produksi karkas itik lokal jantan umur delapan minggu. Buletin Peternakan. 38 (3): 157 - 162.

Leke, J. R., M. Najoan dan O. Sjofjan. 2012. Nilai kecernaan zat-zat gizi limbah Ikan Cakalang (Katsuwonus pelamis L) pada Ayam Kampung. Workshop Nasional Unggas Lokal. Universitas Sam Ratulangi. Manado. Hal : 129 134.

Maghfiroh, K., I. Mangisah dan V. D. Y. B. Ismadi. 2012. Pengaruh penambahan sari jeruk nipis (Citrus aurantifolia) dalam ransum terhadap kecernaan protein kasar dan retensi nitrogen pada itik magelang jantan. J. Anim. Agric. 1 (1) : $669-683$.

Malik, A., E. Suprijatna., V. D. Yunianto dan L. Djauhari. 2015. Pengaruh isoflavon ampas kecap terhadap antioksidan dan rasio kholesterol LDL/HDL darah ayam petelur. Seminar Nasional hasil - hasil penelitian dan pengabdian LPPM Universitas Muhammadiyah Purwokerto. Hal : 252 - 258.

Min,Y. N., F. Yan, F. Z. Liu, C. Coto, dan P. W. Waldroup. 2009. Effect of various dietary enzymes on energy digestibility of diets high in distillers dried grains with solubles for broilers. J. Appl.
Poult. Res. $18: 734-740$.

Mc Donald, P., R. A. Edwards dan J. F. D. Greennalgh. 1977. Nutrition. 2nd Ed. The English Language Book Society and Longman, London.

Payne, R. L., T. D. Bidner, L. L. Southern dan K. W. Mc Millin. 2001. Dietary effects of soy isoflavones on growth and carcass traits of commercial broilers. J. Poultry Science. 80 : $1201-1207$.

Rambet, V., J. F. Umboh, Y. L. R. Tulung dan Y. H. S. Kowel. 2016. Kecernaan protein dan energi ransum broiler yang menggunakan tepung maggot (Hermetia Illucens) sebagai pengganti tepung ikan. J. Zootek. 36 (1): 13 -22.

Sukarini, N. E., L. D. Mahfudz dan A. M. Legowo. 2004. Pengaruh penggunaan ampas kecap yang diproses dengan larutan asam asetat untuk pakan terhadap komposisi kimia daging dada ayam broiler. J.Ind. Trop. Anim. Agric. 29 (3) : 129 - 135.

Tavernari, F. C., L. F. T. Albino, R. L. Morata, W. M. D. Júnior, H. S. Rostagno dan M. T. S. Viana. 2008. Inclusion of sunflower meal, with or without enzyme supplementation, in broiler diets. J. Poultry Science. 10 (4) : 233 -238 .

Widayati, E. dan Y. Widalestari. 1996. Limbah untuk Pakan Ternak. Trubus Agrisarana. Surabaya.

Winedar, H., S. Listyawati dan Sutarno. 2006. Daya cerna protein pakan, kandungan protein daging, dan pertambahan berat badan ayam broiler setelah pemberian pakan yang difermentasi dengan Effective Microorganisms-4 (EM-4). J. Bioteknologi. 3 (1) : 14 -19. 